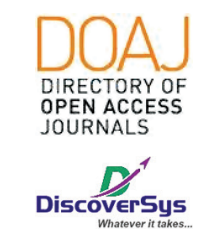

Published by DiscoverSys

\section{The association between wasting nutritional status and delayed of child development in children age 12 - 60 months in Wangaya General Hospital, Denpasar, Bali}

\author{
Michelle Husin, ${ }^{1 *}$ Gede Wikananda, ${ }^{2}$ I Wayan Bikin Suryawan ${ }^{3}$
}

\title{
ABSTRACT
}

Background: Sub-optimal nutritional status in Indonesia is still a continuing problem. There is no significant change in the prevalence of sub-optimal nutritional status. First 1000 days of life is a golden period of brain development. Failure of providing adequate nutrition can lead to the deviation of child development.

Objective: To investigate the association between wasting nutritional status and delayed child development

Methods: A cross sectional study was conducted in this study. Fifty eligible subjects were taken from April 2018 to July 2018 using consecutive sampling methods. Characteristics such as child age, sex, exclusive breastfeeding status, birth weight, birth height, current weight, current height, nutritional status, prematurity, and mother's working status recorded. Child nutritional status was recorded and assessed with the WHO growth chart. Child developmental status was measured with the pre-screening development questionnaire (KPSP). Score $\leq 8$ was assumed as a deviation in child developmental status.

Results: Wasting nutritional status is significantly associated with child development ( $\mathrm{p}=0.041, \mathrm{Cl}-0.013-0.096)$. Prevalence ratio is 3.5 shows that wasting nutritional status is a risk factor for delayed child development. Domain for child developmental delay was $54,5 \%$ has language \& speech delay, $36,4 \%$ has a gross motor delay, and $9,1 \%$ has social \& independency delay.

Conclusion: There is an association between wasting nutritional status and delayed child development. The most often child developmental delay found is speech delay.

Keywords: Child developmental status, KPSP, nutritional status, wasting

Cite This Article: Husin, M., Wikananda, G., Suryawan, I.W.B. 2019. The association between wasting nutritional status and delayed of child development in children age 12 - 60 months in Wangaya General Hospital, Denpasar, Bali. Intisari Sains Medis 10(2): 448-451. D0I: 10.15562/ism.v10i2.384

${ }^{1}$ Researcher General Practitioner/ Child Health Department, Wangaya General Hospital, Denpasar, Bali.

${ }^{2}$ General Practitioner/ Cardiovascular Department Tabanan General Hospital, Tabanan, Bali

${ }^{3}$ Child Health Department, Wangaya General Hospital, Denpasar, Bali
${ }^{*}$ Correspondence to: Michelle Husin; Researcher General Practitioner/Child Health Department, Wangaya General Hospital, Denpasar, Bali; agmichellehusin@gmail.com

Received: 2019-12-05 Accepted: 2019-05-26 Published: 2019-08-01

\section{INTRODUCTION}

In 2015, Millenium Developmental Goals (MDGs) had been changed into Sustainable Developmental Goals (SDGs). There is still an unsolved problem in health sectors about nutrition. Nutrition problem is a common problem in developing countries. Nutrition problem can be divided into wasting, stunting, and underweight.

Nationally, the prevalence of child wasting in 2007 was $18,4 \%$, in 2010 it was $17,9 \%$, in 2013 it was $19,6 \%$. According to Riskesdas, prevalence of child wasting in Bali at 2014 was $10,2 \%$ which was the lowest among other provinces in Indonesia. ${ }^{1,2}$

Undernutrition is one of the factors that can cause a disturbance in child growth that can lead to stunting, disruption of brain development, cognitive problem, less productivity, and others. Child development consists of gross motor aspect, fine motor aspect, language and speech, social \& independence, cognitive, and daily activities.

Early detection of developmentally delayed in children is important to do an earlier intervention to optimize their next milestone in development.
Based on the aforementioned above, this study aims to know the association between wasting nutritional status and delayed child development.

\section{METHODS}

A cross sectional study was obtained to children age 12 until 60 months in the pediatric ward (Kaswari Ward) in Wangaya General Hospital from April 2018 to July 2018. Demographic information about sex, age at the examination date, exclusive breastfeeding status, birth weight, height at birth, current weight, current height, nutritional status, prematurity, and mother's working status were listed. Inclusion criteria were children age 12 until 60 months who was an inpatient in Kaswari Ward. Exclusion criteria were obesity, severely malnourished, congenital disease, syndromes, metabolic disease, and chronic disease. Nutritional status is assessed using the WHO growth chart. Child development was assessed with Kuesioner Pra Skrining Perkembangan (KPSP).

Data were analyzed statistically using SPSS 21.0 for Macbook. Fisher test was performed for the 
independent categorical data, using the significance level of $5 \%$ and a confidence interval of $95 \%$.

\section{RESULTS}

Fifty-eight subjects were eligible include in this study. However 8 subjects were excluded (immunocompromised $=4$ patients, chronic disease $=1$ patient, severely malnourished $=1$ patient). Total subjects analyzed were 50 (Table 1). There were 8 subjects had a wasting nutritional status, and 42 subjects had not wasted nutritional status.

To know the association between wasting nutritional status and delayed of child development hypothesis test using Fisher was done.
The Fisher-test found a statistically significantly difference between wasting nutritional status and delayed of child development $(\mathrm{p}=0.041$, CI $95 \%=-0.013-0.096)$.

There were 10 subjects who had a delay in child development. 1 subject had 2 domains of developmental delay which made there were 11 total of delays. That one subject had delayed in both language \& speech and gross motor according to the KPSP for age 12 months. 4 subjects had a delay in language \& speech according to the KPSP for age 12 months. 1 subject had a delayed in language \& speech according to the KPSP for age 48 months. 3 subjects had a delay in a gross motor according to the KPSP for age 24 months, 30 months, and

Table 1 Baseline characteristic of respondents

\begin{tabular}{|c|c|c|}
\hline Characteristics & Total (n) & Percentage (\%) \\
\hline \multicolumn{3}{|l|}{ Sex } \\
\hline Male & 28 & 56.0 \\
\hline Female & 22 & 44.0 \\
\hline \multicolumn{3}{|l|}{ Age } \\
\hline $12-24$ months & 26 & 52.0 \\
\hline $25-36$ months & 12 & 24.0 \\
\hline $37-60$ months & 12 & 24.0 \\
\hline \multicolumn{3}{|l|}{ KPSP Age } \\
\hline $12-24$ months & 31 & 62.0 \\
\hline $25-36$ months & 12 & 24.0 \\
\hline $37-60$ months & 7 & 14.0 \\
\hline \multicolumn{3}{|l|}{ Nutritional status } \\
\hline Not wasted & 42 & 84.0 \\
\hline Wasted & 8 & 16.0 \\
\hline \multicolumn{3}{|c|}{ Exclusive breastfeeding status } \\
\hline Yes & 29 & 58.0 \\
\hline No & 21 & 42.0 \\
\hline \multicolumn{3}{|l|}{ Birth weight } \\
\hline$<2500$ gram & 5 & 10.0 \\
\hline$>=2500$ gram & 45 & 90.0 \\
\hline \multicolumn{3}{|l|}{ Prematurity } \\
\hline Aterm & 46 & 92.0 \\
\hline Preterm & 4 & 8.0 \\
\hline \multicolumn{3}{|l|}{ Mother's status } \\
\hline Working & 27 & 54.0 \\
\hline Not working & 23 & 46.0 \\
\hline
\end{tabular}

Table 2 Association between wasting nutritional status and delayed of child developmental

\begin{tabular}{lcccc}
\hline Nutritional status & Delayed & Not delayed & P-Value & Cl 95\% \\
\hline Wasted & $4(8.0 \%)$ & $4(8.0 \%)$ & 0.041 & $-0.013-0.096$ \\
Not wasted & $6(12.0 \%)$ & $36(72.0 \%)$ & & \\
\hline
\end{tabular}


Table 3 A domain of developmental delay in Kaswari Ward

\begin{tabular}{lcc}
\hline Domain & Total (n) & Percentage (\%) \\
\hline Language \& speech & 6 & 54.5 \\
Gross motor & 4 & 36.4 \\
Fine motor & 0 & 0.0 \\
Social \& independency & 1 & 9.1 \\
Total & 11 & 100.0 \\
\hline
\end{tabular}

36 months. 1 subject had a delayed in social \& independency according to KPSP for age 42 months.

The group age that had the most delayed was group age $12-24$ months. 6 subjects had delayed in this group age. There were 2 subjects in the group age 25 - 36 months that had delayed. There were also 2 subjects in the group age $37-60$ months who had delayed.

Prevalence ratio was 3.5 which shows wasting nutritional status increased the risk 3.5 times more to had a delay in child developmental.

\section{DISCUSSION}

It is well known that the golden period for child developmental is during the first 1000 days of life. Lack of nutrition, infection, and inflammation are some factors that can affect child development, especially in the developing countries. ${ }^{3}$ According to research in RSCM global developmental delayed can be caused by microcephaly, wasting nutritional status, and severely malnourished. ${ }^{4}$ In some research in Bandung, factors that can affect child development are age, mother's formal education, family income, and living place. ${ }^{5}$ In an analysis in Kudus Region, exclusive breastfeeding status and maternal risk factor while pregnant are a significant risk factor for developmental delayed in children.

In this study, there is a significant association between wasting nutritional status and delayed in developmental in children. This result is consistent with the earlier findings from Suhartiningsih etc., Kasenda, etc, Sholicha, etc, and Humaira etc. ${ }^{6-9}$ Different results seen in the findings of Gunawan, etc which found there is no association between developmental delay and wasting nutritional status in children. ${ }^{10}$

The domain of developmental delay found in this study from the most common to the least is language \& speech, gross motor delay, and social $\&$ independence. No fine motor delay was found in this study. A study from Suwarba etc. in child neurology clinic in RSCM found the most common case in child developmental delay is the delay in walking and speaking. ${ }^{4}$ This result is also consistent with the study from Fadlyana etc. which distinguish the difference of developmental delay in children in rural and urban area which found language \& speech as the most common delay either in the urban or rural area. ${ }^{5}$ According to a study from Gunawan etc. the most common delay found in children is gross motor delay. ${ }^{10}$

In this study, the most delayed found in group age $12-24$ months. A study from Fadlyana etc. found delayed in developmental mostly found in children below 2 years old. ${ }^{5}$ This is a crucial age which nutrition, infection, and inflammation has an important role that can affect a child's development in this period. ${ }^{3,11}$

From this study, we can conduct that wasting nutritional status can increase the risk 3.5 times to have a delayed in child development. It is consistent with the theory that child developmental is affected by adequate nutrition in the first 1000 days of life. ${ }^{3,6,12-15}$

In this study, weight for height (WFH) is used to assess the nutritional status in children which more likely to show an acute nutrition status more than a chronic nutrition status. Acute nutrition status can be influenced by recent child's condition such as a climbdown in weight because of acute illness. For further study, height for age (HFA) is more appropriate to assess children nutritional status for a chronic assessment.

\section{CONCLUSION}

There is an association between wasting nutritional status and delayed child development.

\section{ETHICAL CLEARANCE}

Ethical approval has been obtained from ethics of committee prior to the study conducted.

\section{CONFLICT OF INTEREST}

The authors declare that there is no conflict of interest regarding manuscript.

\section{FUNDING}

The authors are responsible for the study funding. 


\section{AUTHOR CONTRIBUTION}

All authors are equally contributed in this study from main concept, statistical analysis, until data synthesis, and manuscript preparation.

\section{REFERENCES}

1. Riset Kesehatan Dasar. Badan Penelitian dan Pengembangan Kesehatan. Kementrian Kesehatan RI. 2013.

2. Situasi Gizi di Indonesia. Infodatin: Pusat Data dan Informasi Kementrian Kesehatan RI. ISSN 2442-7659. 2016.

3. John CC, Black MM, Nelson CA 3rd. Neurodevelopment: The Impact of Nutrition and Inflammation during Early to Middle Childhood in Low-Resource Settings. Pediatrics. 2017; 139(Suppl 1):S59-S71.

4. Suwarba IGN, Widodo DP, Handryastuti RAS. Profil Klinis dan Etiologi Pasien Keterlambatan Perkembangan Global di Rumah Sakit Cipto Mangunkusumo Jakarta. Departemen Ilmu Kesehatan Anak FK Udayana dan FKUI. Sari Pediatri 2008; 10:4:255-42.

5. Fadlyana E, Alisjahbana A, Nelwan I, Noor M, Selly, Sofiatin Y. Pola Keterlambatan Perkembangan Balita di daerah Pedesaan dan Perkotaan Bandung, serta Faktorfaktor yang Mempengaruhinya. Sari Pediatri. 2003; 4(4): 168-174.

6. Suhartiningsih S, Putri MA. Hubungan Status Gizi Bawah Normal dengan Perkembangan Motorik Kasar pada Balita Usia 6 - 60 Bulan. Jurnal Keperawatan dan Kebidanah: Stikes Dian Husada Mojokerto. 2010:100-6.

7. Kasenda MG, Sarimin S, Obnibala F. Hubungan Status Gizi dengan Perkembangan Motorik Halus pada Anak Usia Prasekolah di TK GMIM Solafide Kelurahan Uner Kecamatan Kawangkoan Induk Kabupaten Minahasa. Ejournal keperawatan (e-Kp). 2015; 3(1):1-8.
8. Scharf RJ, Scharf GJ, Stroustrup A. Developmental Milestones. Pediatr Rev. 2016; 37(1):25-37.

9. Humaira H, Jurnalis YD, Edison E. Hubungan Status Gizi dengan Perkembangan Psikomotorik Balita di Wilayah Kerja Puskesmas Lapai Padang. Jurnal Kesehatan Andalas. 2016; 5(2):402-408.

10. Gunawan G, Fadlyana E, Rusmil K. Hubungan Status Gizi dan Perkembangan Anak Usia 1-2 Tahun. Sari Pediatri. 2011; 13(2):142-6.

11. Attanasio O, Fitzsimons E, Grantham-McGregor S, Meghir C, Rubio M. Early childhood stimulation, nutrition, and development: a randomised control trial. Institute for Fiscal Studies. 2012.

12. Irwanto, Suryawan A, Narendra MB. Penyimpangan Tumbuh Kembang Anak dalam Kapita Selekta Ilmu Kesehatan Anak ed. 6. Divisi Tumbuh Kembang Anak FK Unair RSU Dr. Soetomo. PKB XXXVI. Surabaya. 2006.

13. Fewtrell M, Michaelsen KF, van der Beek E, van Elburg R. Growth in Early Life: Growth Trajectory and Assessment, Influencing Factors and Impact of Early Nutrition. John Wiley \& Sons: Australia. 2016.

14. Windiani T. Infant Growth Assessment. Proceedings of the KONIKA XVII Jogjakarta; 2017.

15. Hurley KM, Yousafzai A, Lopez-Boo F. Early Development and Nutrition: A Review of the Benefits and Challenges of Implementing Integrated Interventions. Adv Nutr. 2016; 7(2);357-363.

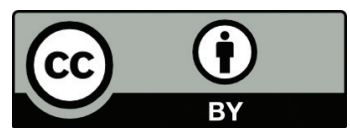

This work is licensed under a Creative Commons Attribution 